DOI: https://doi.org/10.47405/mjssh.v6i5.802

\begin{tabular}{|c|c|}
\hline & Malaysian Journal of Social Sciences and Humanities (MJSSH) \\
\hline Malaysian Journal of & Volume 6, Issue 5, May 2021 \\
\hline (MJ-sSH) & e-ISSN : 2504-8562 \\
\hline & $\begin{array}{l}\text { Journal home page: } \\
\text { www.msocialsciences.com }\end{array}$ \\
\hline
\end{tabular}

\title{
The Portrayal of The Image of Love in Hemingway's Selected Novels
}

\author{
Hussein Mnahi Munshid', Abdul Ghani Ahu' \\ 1Departmentof English Language and Literature, Faculty of Language and Communication, Universiti Pendidikan \\ Sultan Idris (UPSI) \\ Correspondence: Hussein Mnahi Munshid (mnahil1973@gmail.com)
}

\begin{abstract}
The researcher tries to output a sufficient analysis for selected texts of Hemingway to reflect how his characters has demonstrate the image of love. The analysis for Hemingway's texts aims to offer a typical answer to the question, which was to what extent did Hemingway portray the image of love in his selected novels. While going through and trace Hemingway's characters, the researcher discovers that all of them have been emotional where love comes as a changing factor in their life. Love concept has been display in many portraits such as physical, spiritual and love for God. The main themes were discussed and analyzed psychologically by tracing group of heroes and heroines who live, represent and portray these topics though the great modernist American author Ernest Hemingway in his selected novels.
\end{abstract}

Keywords: love, marriage, sacrificing, physical, spiritual, image, nature

\section{Introduction}

Through this segment, the researcher tries to output a sufficient analysis of the selected novels to reflect how Hemingway has portrayed the image of love in his novels. The researcher will analyze the objective in this study to offer a suitable justification for Hemingway's contrasting portrayal of the image of love. The researcher analyzes these texts Psychologically to discuss the main themes by tracing group of heroes and heroines who live, represent and portray these topics though the great modernist American author Ernest Hemingway in his selected novels, A Farewell to Arms, For Whom the Bell Tolls, The Sun Also Rises and The Old Man and the Sea.

Referring to the main themes in the statement of the problem and the first research question, the researcher achieve that all the characters of the novels in a way or another serves to depict the various images of love that Hemingway wanted to portray and after going deeply throughout four of Ernest Hemingway's novels. The researcher summarizes the findings of this study to prove that there is an effect of the war violence on the image of love through analysis of Hemingway's characters who successfully portrays the image of love in different situations.

\section{The Portrayal of Love}

Love portrait in AFA is important and has many variations. Love comes as a changing factor in Henry's life because he becomes immersed in it so much so that even in the midst of the battle he 
cannot forget Catherine. Their love was during an ugly war, but it is so potent that it brings about an inner transformation in him. Assadnassab (2005) asserted that "Their relationship brings value to his life, which Frederic has realized in love". Actually, he does not fall in love with Catherine until he is injured and is put in a hospital. It is a story of one man's withdrawal from war into the love, though it ends in futility.

Love concept has been displayed in many portraits such as amorous love, true love, love for God, Rashid (2013) said: "Frederic lives up to its fullest; in that world, the view of life the priest is not acquainted with because the priest loves God.", also, there is the love for friends, Rinaldi tells Frederic that "We are brothers and we love each other" (AFA, P.50)

Lieutenant Frederic Henry, the hero of the novel is a young American soldier attached to an ambulance unit on the Italian Front. As the novel advances into action, we find him in love with Catherine Berkley, a British nurse, after he had been admitted to the hospital. The story revolves around these two characters and the war. After heavy gunfire in which the Austrians suffered many casualties, the Germans reinforced them. Their attack was more violent and compelled Italian armies to retreat. During this terrible retreat, Frederic was spotted by the enemy officers and tried by a summary court-martial, a military court. It condemned him to death. Fredric, however, escaped through the river on a log of wood. He crossed the great plain on foot, and then jumped aboard a goods train and reached to his beloved Catherine in Milan hospital (Fernando, 2003).

The two central characters of this novel Frederic Henry and Catherine Barkley struggle life and death in the novel where she dies, in the end, leaving Frederic as a victim of the traumatic experience. War outlasts lovers. War is displayed not in the terms of any classic sense but technological warfare where there was less opportunity of verification of manly skill. Rain, a major symbol, accompanies the whole novel from beginning to end designing the doom and despair of mankind.

Pathan (n.d) wrote that Henry is a young American ambulance driver with the Italian army, turns from the horrors of war to a passionate love affair with Catherine Barkley, and the all-consuming love helps distract him from the brutality around him. Still, he is good at his job; a cool-headed, unselfish man who exercises grace under pressure when he is injured and when he must shoot a deserting engineering officer. Henry makes his "separate peace" when he decides that he no longer has any obligation to the army and that his loyalty is to Catherine.

Hemingway repeatedly emphasizes the horrific devastation war has wrought on everyone involved. From the opening account of cholera, that kills 7,000 men to the graphic description of the artillery bombardment to the corrupt violence during the Italian retreat. Henry frequently reflects upon the world's insistence on breaking and killing everyone, it is as if the world cannot bear to let anyone remain happy and safe.

Indeed, whenever Henry and Catherine are blissful, something comes along to interrupt it, be it Henry's injury, his being sent back to the front, his impending arrest, or, finally, Catherine's death from childbirth. With such misery confronting them at every turn, the two turn to each other. Catherine, especially, plunges almost too easily into love when she first meets Henry. She admits she was crazy at first, most likely over the fairly recent death of her fiancé, but Henry, too, succumbs to the temptations of love.

Love is a pleasurable diversion that distracts lovers from the outside world; the two often tell each other not to think about anything else, as it is too painful. Hidden within the shelter of Catherine's beautiful hair, Henry and Catherine feel protected from the cruel outside world. The major problem with such escapist love is, as Henry and other characters point out several times, one does not always know the stakes of love until it is over, or that one does not know about something until one has lost it. Henry hardly allows himself to think of life without Catherine while he is in love, and once he does lose her, it seems unlikely that he will recover (Pathan, n.d.). 
In the same context, Pathan (n.d) stated that at the start of the novel, Catherine is in grief over her fiancé's recent death where he has blown into pieces on the Western front. Henry offers a tempting rebound, and she dives into this new diverting love. She later admits that she was slightly crazy when she first met Henry, and her behaviour backs this up: she gives herself so readily to a near stranger, and her games of flirtation and teasing border on the juvenile. However, she gains some measure of independence later on, as when she helps Henry row the boat across the lake for their escape, but she is typically submissive and eager to please with Henry. Like Henry, she believes the world is out to destroy people's happiness.

In For Whom the Bell Tolls, Hemingway has constructed the characters of Maria and Robert Jordan in intrinsic ways. The writer also portrayed the same two kinds of love: amorous and real. Hemingway, form his part, immerses the reader in different images of love, hatred, sex, hope, and despair of three days of battle in the spring of 1937. It is obvious that Robert Jordan has a powerful sexual and emotional bond with Maria.

The Sun Also Rises like Hemingway's previous novels has physical love and spiritual love. Hemingway portrayed love in this novel dramatically. Love is changed or inversed from a spiritual to physical and the main reason is this change is Jake's impotence and the emotional vacuum that resulted from the war.

It is difficult to separate Hemingway the man from Hemingway the writer because most of his writings are in one way or another related directly to his personal life. This novel of the blue marlin came from Ernest Hemingway's own experience of deep-sea fishing in his first visit to Cuba. Hemingway fished his first marline in the water of Havana. Hemingway's passion for hunting these magnificent and glorious fish never forgettable, nor his admiration and respect fade for the Cuban fishermen to whom the marlin was their livelihood. Ernest Hemingway's writing depicted a way of life that illustrated his view of the role of the man.

His father instilled in him the power of adventure, the love of nature as well as the suspense of the wildlife. He was very stubborn and perseverant to reach his aims the fruition in wild nature (Imane, 2014). His loving for nature and its living things is reflected also through the fisherman's attitude that man is part of the cycle of life; today's hunter could be tomorrow's prey and man should fight in order to win and survive; thus man is seen as an individualist within the larger system of life, this is seen through the general development of the plot in which Santiago wins over the great marlin but later losses it to the sharks.

\section{The Physical Love}

This kind of love is represented by Hemingway's character Frederic Henry when he was trying to seduce Catherine Barkley. He knows that he neither loves Catherine nor has any intention of loving her. He says, "This was a game like Bridge in which you said things instead of playing cards" (AFA, 38). The first meeting between these two characters begins with a flirtation and with a seduction intention to seduce Catherine. Raj (2016) wrote, "lt is mere flirtation for Henry is attracted towards her as a child towards a toy"(p.6). She was a doll in the eyes of Frederic. It is simply a casual affair, particularly from Frederic's side who was a happy-go-lucky young man, fond of wine and visits brothels along with his companions.

Moreover, Ganjoo (2014) stated, "It was an order of the day for youth during wartime to indulge with women in amorous adventures"(p.6). Catherine and Henry are instantly attracted to each other but Henry considered their relationship as a wartime flirtation which is a little better than making love to one of the girls at the Villa Rossa, the officers' brothel. Henry goes there during his leave then goes to the cities and spends his nights drunk in hotel rooms.

The protagonist is aware that man is trapped right from birth, so he spends most of his time visiting brothels and drinking heavily. At this point in Henry's life, drink and sex are both escape symbols. 
Alexis, Lanior and Theophilus (2014) shared that "He devotes himself to fulfil these appetites and the desire to satisfying ephemeral appetites...."(p.2). He is afraid of the darkness because it is like the darkness of death. He is restless and cannot face sleeping in a dark room and this fear forces him to search for some type of sensation during the night. He prepared to make the best use of every minute in his lifetime.

Henry's reactions to Catherine at first were a physical and a trifling flirtation. His affair with her achieving sexual fulfilment and leading to a pregnancy. Rashad has reported that "Women are an inspiration, muses, sexual temptation and release from sexual tension". She slept with Henry on the very first opportunity. The war had taught her to live her day. There are no more absolutes left in her life. It is a direct and logical result of immoral social situations because of the war. Love like war takes place and is a stormy affair and just as war ends in time so does love ends in separation or death.

Hemingway substituted the role that Henry played in A Farewell to Arms by the playful role that Maria had taken in For Whom the Bell Tolls. From the beginning, Maria had flirted Robert in an attempt to seduce him. She had used her sexy cropped hair as a medium for their mutual seduction.

He ran his hand over the top of her head. He had been wanting to do that all day and now he did it, he could feel his throat swelling. She moved her head under his hand and smiled up at him and he felt the thick but silky roughness of the cropped head rippling between his fingers. Then his hand was on her neck and then he dropped it (FWBT, 37).

Maria approached Robert and pursued him in his bed. Maria has a sexual and emotional relationship with Robert Jordan. From his side, Robert was waiting to do that because he loves Maria back.

She approached him in his sleep, and it is she who eventually pursued him in his bed. What supports this seduction the continuous encouragement and counselling from Pilar to Maria in her sexual and emotional relationship with Robert Jordan, she often acts as a mentor to Maria. As concerning to Pilar who was intensely sexual, she was openly discussing sex and her previous sexual relationships, particularly with a bullfighter with whom she was in love for many years. Pilar said in her deep lovely voice. "And if the Maria kisses thee again I will commence kissing thee myself. It's years since I've kissed a bullfighter, even an unsuccessful one like thee, I would like to kiss an unsuccessful bullfighter turned Communist. That night, she tells Robert Jordan and Maria, she slept with Pablo but, at his request, they did not make love. He believed it would have been in "bad taste after the killing of so many people" (p. 128).

Pilar is the lover of a ruthless male guerilla leader named Pablo. She is also the exlover of a bullfighter, the matador, Finito who was fatally wounded while killing his last bull. He was brave despite his fear of the bulls, in contrast to Pablo, who in his drunken state refused to participate in the attack on the bridge ". . . after the funeral, she took up with Pablo who led picador horses in the ring and was like all the bulls that Finito had spent his life killing. But neither bull force nor bull courage lasted, she knew now... (FWBT, p.105).

When the gypsy eventually reappeared, he was proudly carrying two hares he had tracked. The scene might well portend Robert Jordan's falling in love, there is also a sexual hint to his affairs with Maria when Rafael followed the hares because they were "making love in the snow" (p. 149), and Robert Jordan began calling Maria his "little rabbit" (FWBT, p.71) the night of their first sexual encounter.

Robert and Maria joyfully make love after they profess their love for each other and Maria asks to be his woman. He says that cannot be in the light of his task in the war, but she insists. She tells him that she had never willingly been with a man before but had been raped, but he assures her that true love wipes away all such misfortunes (Janiesch, 1985). Jordan and Maria fall in love and become intimate; they hope to marry and go to America eventually, but they also realize that in their present situation they must seize every moment of pleasure while they can. So they make love many times, they make 
love in the heather. Moreover, they make love outside the cave in the sleeping bag, and then fall asleep in one another's arms.

Much of the central conflict in The Sun Also Rises has to do with anxieties regarding sex. Relationships between women and men in this novel are riddled with conflict, as is apparent in Brett's quarrels with her various lovers. In this novels Hemingway portrays Brett is establishing relationships with different personalities, she abandoned her fiancé Mike for Pedro Romero and abandons Cohn for the sake of Jake. The best example of Brett's ability to function as the initiator of physical love in her interaction with Pedro Romero. In this affair, Brett holds the role of the initiator of the relationship by finding Romero so that she can begin an affair with him. Her intent in finding Romero is clear in that, so she said, "I'm mad about the Romero boy. I'm in love with him, I think" (SAR, P.167). It is clear that Brett intends to begin a sexual relationship with Romero.

After she gets a divorce from her husband, it quickly becomes clear that she loves to tease men and have affairs with them, but incapable of having any real deep feeling for anyone. She loves Jake despite her rejection of him because of his impotence. Brett selects the men with whom she desires to have a sexual relationship and then pursues them only to later forcibly end the affair. This pattern, with some variations, is seen in her interactions with both Romero and Cohn in a more obvious way and with Jake and Michael in a less direct fashion (Yu, 2010).

Hemingway makes clear that Brett cannot help herself. Brett has been wounded by love. She seeks to re-establish the special world of lovers. She is one of Hemingway's bad women, but even as she invades and violates the masculine, she offers to Jake and Romero and Robert Cohn alike the supreme allurement of a beautiful woman aroused to an insatiable passion. She, like the men she attracts, is sick with unrequited love. She is a threat to men because she forces them to recognize the sexual interest of their desire and the fragility of male bonding when threatened by lust, sexual need, or competition for a woman.

The Paris section of the novel is filled with negative portraits of women, the prostitute with bad teeth, rich and superficial women who seek marriage when they have lost their looks and destroy the freedom of men. Hemingway provides some explanation for the behaviours of this category of women who could be termed as Bitches, explaining the forces and the circumstances that have been responsible for shaping them into what they are. Brett is frequently portrayed as drunkard, unnatural, bold, and nymphomaniac. It seems that her abnormality is an attempt to conceal her pain and to find substitute comforts for true love. Actually, Brett appears honest and she hopes to find in the drug of sex a way to forget the future and the past.

Many factors destroy true love and turn it into physical. According to the social psychology, the insufficiency in certain factors like proximity, similarity, needs, care, and intimacy lead to destroy true love to be physical and makes the two lovers or one of them to be amorous person, maybe alienated from each other and creating a vacuum that has to be filled by someone else. Impotence is one of the most important factors that has led to insufficiency.

\section{The Spiritual Love}

The second image is real love. It shows the growth of Frederic and Catherine's relationship as they spend time together in Milan. The realization of his love for Catherine comes with the realization of himself after he gets hurt on the Italian front. Frederic fell in love with Catherine and had fled with her to Switzerland where they had enjoyed life and lived in a world of their own. There they had no longer been threatened by war.

At first, Henry's reactions to Catherine were physical. He would prefer to sleep with her than go to the house of prostitution. But he becomes more and more involved with Catherine. He sees in their relationship a type of order, a type of commitment to a regular existence. Love in A Farewell to Arms is not a sentimental affair where lovers cry and long for one another. The concept of love is realistic 
and an urgent need of body and mind which explains why lovers in the novel establish sexual and emotional intimacy (Kumar, 2013).

To find out how something happens, it is important to ask why it has happened in this way or what the main reason behind. Therefore, to know how Henry's love for Catherine has been changed from sexual to spiritual, it is important to ask about the reason behind this change. According to Rubin (1974), "love is an attitude. The attitude predisposes one to feel in a particular way towards the beloved".

Change in love is a kind of change in attitude from non-persuasion state to persuasion and vice versa. The change is not arbitrary and uncontrolled but depends on firm theoretical foundations. In A Farewell to Arms Henry's love for Catherine changed from ludus (game-playing love) to agape or altruistic (selfless love) in referring to John Lee (1973) and Hendrick (1986). There are many factors that influence in creating love or participate in changing love from an amorous to true love, such as proximity, similarity, intimacy, need and care. Perhaps one of these factors will be enough to inflame the spark of love or may the interaction of two or more factors contribute to persuading a person to change his mind and make it more serious and more committed to his relationship with the beloved.

When Hemingway portrayed Henry and Catherine, there was a similarity and proximity in the social and psychological conditions of the two characters. Henry and Catherine were out of their countries participating in World War I where Catherine was a nurse and Henry was a soldier in the Italian front. Both are suffering from war. Catherine lost her boyfriend in France and Henry was wounded by a shell of Mortar. Both have lost true love and a sense of security and have feelings of isolation, alienation. Proximity and similarity create interpersonal attraction. According to Asch (2011), he stated that "the more similar two people are in attitude, background and other traits the more probable it is that they will like each other".

The greater the danger and horror of war, the more tender and romantic is love in Hemingway's fictions, the balance is perfect. This is clearly demonstrated in the violent novels of Hemingway. In A Farewell to Arms, the author first places the protagonist far from the violence and fight. Consequently, he is unable to love. Nevertheless, when Frederic Henry becomes involved in the events of the conflict, a passionate love not only springs up but develops within him parallel to the progressive intensity of danger that the protagonist experiences.

Real love meets a great need in Henry's life, which is filled with brutality and ugliness. Henry fell deeply in love with Catherine; the extent of his emotional involvement to her can be made out from his reply to Count Greffi's question, "What do you value most?" Henry replies, "Someone I love" (AFA, $353)$ and also when he later says about her that "I loved her very much and she loved me" (AFA, 142) and "Besides all the big times we had many small ways of making love"(AFA,149).

Like Henry, Catherine is also found in a similar condition, has lost her fiancé at the battlefield. She in her heart is very much clear about the loss of somebody who has been very dear. She wants the replacement of her fiancé. This is one of the reasons why she falls in love with Frederic Henry. This clearly represents the influence of two factors: need and similarity in creating love in Catherine's heart towards Henry. While the caring factor has been represented in Catherine as a nurse. She heals the wounded soldiers and as a beloved cures Henry who is physically and psychologically wounded in the war. Her pregnancy, her desire for domestic life, home image, purchasing of baby clothes and Henry's proposal for marriage and many other events that could be a clear manifestation of the portrayal of the factor intimacy.

Catherine Barkley has no religion because she has lost her faith in conventional religion she says "But I haven't any religion" (AFA, 149). For Catherine, love becomes a religion; she has made a religion out of her love to Frederic. She tells Frederic, "You're my religion. You're all I've got"(AFA, 149). He has become everything in her life so that she does not want to lose him. She was apparently hit hard by the loss of her lover but that event has not destroyed her vulnerability. 
True love achieves a kind of balance between man and woman, harmony between people, Hemingway has said that this kind of harmony is the most difficult thing to struggle to feel consciousness, know themselves and the nature of relationships. Knowing yourself and others to create love is important. Maria Sans, a Spanish nurse whom Hemingway met during the war, was the basis for Jordan's great love. The self- indulgence of the love relationship between Jordan and Maria is sensitive to the point of obsession. "Stop it, he told himself. You have made love to this girl and now your head is clear, properly clear, and you start to worry" (FWBT, p.161). He had already told her "I love thee, Maria ... And no one has done anything to thee. Thee, they cannot touch. No one has touched thee, little rabbit". He falls passionately in love with Maria. He loves her in a way that he has never experienced before.

During the three days and nights that Jordan spends in the guerilla's cave, he awaits with a romantic opposition to heroism what he suspects will be his destruction and that of his companions. He falls in love with Maria, daughter of a Republican mayor. Maria saw her parents killed before her eyes and was raped by the Fascists. Her close-cropped hair is a symbol of her tortures as it is shaved regularly in prison, Jordan helps her to regain her desire to live. While Jordan and Maria's passionate love is abetted by the powerful woman Pilar, who dominates the group by her force of character, gusto, and love of the Republic. Her man Pablo is wily but lacks belief and hence courage (Hemingway, 1995).

Henry uses some distinct noun phrases in attempting to depict in detail his love for Maria, like, "little rabbit (39), my rabbit (39),. my darling(40), my sweet(40), my long lovely(40), my lovely one(40), a partner(28), the tailor(38), my help(38), my love $(26,27,29,31)$ and so on ..." In that way, additional information about the lady is included and a striking figure of a supportive lady was presented (Mugair, Khadum, \& Khalaf, 2019).

Jake's relationship with Lady Brett Ashley is the central concern of the novel. He is deeply in love with her. In spite of Brett's contrast with Jake, he ignores his feelings and desires whenever they conflict with Brett's requests. He is willing to do anything for her, regardless of the personal cost. Although he loves Brett, he helps her find Romero so that she can sleep with him. Jake thus utterly betrays his own desires. His blind love for Brett overpowers all of his self-interest. Jake's love for Brett is the most powerful, controlling force in his life, and it greatly disrupts everything else that he holds dear. Jake has a genuine passion for her. It is through Brett's love that Jake tries to overcome his sense of alienation. However, as he is sexually disabled, and cannot provide her sexual satisfaction, he is filled with a sense of alienation. Jake is troubled by Brett's inconstancy and yet is not able to detach himself from her (Rani, 2014).

Brett worked as a nurse in a hospital during the war, where she met Jake and fell in love with him. After her lover had been killed in the war. Brett has a high degree of sexual anxiety and she has a desperate need for love and willingness to follow wherever love leads. Their love was true but Brett made up her mind that she cannot be with him probably because he was injured. Although she loved him too much, she was unable to be with him. Similarly, Brett falls in love with Pedro Romero from the first sight and leaves Mike the man who was going to marry her after she has got her divorce from her ex-husband. Finally, Brett quitted her beloved Romero.

Robert Cohn falls in love with Brett and having a sexual relationship with her and they take some days off alone and go on a trip together where they romanced together unknown to anyone else in San Sebastian. Brett abandons Cohn after a short time but it seems that he does not understand that his affair with Brett is over. Cohn is awkward socially and a little slow intellectually at times. He yearns for Brett and follows her around. The way he pins for Brett when he clearly should have to give up is quite pathetic and makes him a target for contempt. During all the period of their stay, he was constantly following Brett everywhere, and this irritated her and angered Mike. Mike mocked Cohn harshly for following Brett around when he was not wanted. He shouted at Cohn, "Why do you follow Brett around like a poor bloody steer? Don't you know you're not wanted?" (SAR, P132) 


\section{The Marriage}

The traumatic experience of war has shattered the institution of family and marriage. War and death are juxtaposed against nature and life. Unlike the war image, another form of love has appeared in this novel which is marriage. According to Catherine, this marriage does not require marriage. The image of marriage between Catherine and Henry is a fruitful marriage because of the sincere love between the two lovers. As far as love is concerned it is an experience sufficient by itself and it does not need to be legalized by marriage. She merges her own personality with Fredric's so much, so that she becomes the only source of Henry's happiness. It is a love that requires no formality of marriage. It is a union of two devoted hearts. Barkley, the typical Hemingway heroine who is monogamous. She offers herself wholly to the man on the altar of love. Henry is her religion. Her love relationship needs neither civil nor religious sanction. She feels that she has already a part of Henry "There isn't any me. I'm you"(AFA, P.84). She needs no formality of marriage.

When Henry learns she is pregnant he wants to get married for her sake but Catherine professes that she already feels like a married woman. "Don't talk as though you had to make an honest woman of me, darling. I am a very honest woman. You cannot be ashamed of something if you're only happy and proud of it." The completeness of her surrender is cleared from the following declarations "I'll say just what you wish and I'll do what you wish were and then you will never want any other girls, will you" and I'll do what you want and say what you want and then I'll be a great success, won't I? And "You see I'll do anything you want" and "I want what you want. There isn't any me anymore. Just what you want" etc. this woman is al worship all adoration for her lover. She says, "I won't ever leave you for someone else. I suppose all sorts of dreadful things will happen. But you don't have to worry about that".

Here Catherine expresses herself as an honest woman and that Henry cannot feel the shame of her. She adds feels like a married woman and there is no need for formalities of marriage. She also expresses her love by saying it is a love for the sake of love, not for the sake of getting married to Henry.

\section{The Sacrificing}

Hemingway's novel concludes by depicting Robert Jordan, the American volunteer in Spain, as he prepares for his death. Jordan accepts the inevitability of this death and he designs a ritual that expresses his commitment to his lover, Maria, and contributes to the successful retreat of the members of the guerrilla band. He provides the last effort of participation in their struggle against fascism and affirms his connection to the future of Spain.

Jordan's death while fighting as a volunteer in the Spanish Civil War is presented as a sacrifice to protect his beloved and his values. Hemingway praises the American Dead in Spain" the volunteers who died fighting to protect republican values. In a report published in 1938, Hemingway wrote of the deaths of such volunteers of the International Brigades, and said, "They die fighting for you" (Hem on War 293). The patriotism, defence of the homeland, comradeship, maturation, the ability to face danger and death, to be ready even for self-sacrifice for a noble aim, love stories related to the frontline, etc. are all expressions parallel to the term of the volunteer.

In the end, Robert Jordan overcomes his fears and sacrificing his life to protect the Guerilla and sending Maria away, He was suffering a fatal wound when he shouted. 'I am with thee now. We are both there. Go!' Reassure her that he will continue to live through and with her: These are Robert Jordan's final words to Maria, spoken as she is led off by Pilar, denied her request to stay with the man she loves. 


\section{The Love for Nature}

Santiago's outlook on the great marlin has a paradoxical viewpoint. Santiago admires the fish and considers it sometimes near and sometimes beyond the human-animal boundary, he said "Fish, he said "I love you and respect you very much. But I will kill you dead before this day ends."(OMS, 40). Santiago was living in a hard situation, and cruel nature, but he was precise, patient, and persevere as he had nothing else but fishing to fill his life with.

Santiago loves not only the Marlin fish but loves many other animals that are mentioned by the old man such as various kinds of fish, turtle, and sharks. All these animals have a reciprocal relationship with the old man. Man likes birds for their friendly company on the sea and they help him to find schools of fish on the sea. He loves turtles and admires that their heartbeats hours after being cut off their body and he eats their eggs to keep strength. He likes flying fish because they are his friends on the sea and he eats them. This reciprocity confirms the strong feeling of natural cycles, of a predator that lives from his prey.

Similarly, the image of love also appears in the human relationship between the old man and the boy Manolin. Santiago has no friends except that boy whose parents forced him to leave Santiago's skiff. $\mathrm{He}$ is described as a young, kind and caring fisherman. Manolin's character embodies features opposite to the old man. Manolin acts as psychical comfort. He expresses all the old man does not have life powers, youth, future, and prospect. He is strong and successful and he acts as a fortifying element of the old man. There exists a close relationship between the characters of Santiago and Manolin. The most noticeable is their attitudes of a teacher and his pupil.

Manolin as a character offers a solution of psychological matters that touch the social and moral dignity of the old man. The old man receiving food, clothes, baits, and help from Manolin. Manolin is aware of the real situation of Santiago, yet he tries to keep Santiago's dignity. He lets Santiago have a feeling of respect, while Santiago is aware of it and accepts the game. In terms of psychology, the reception is an ability to satisfy one's needs. It is a psychological phenomenon related to escape from reality.

There is another image that charges the scene with a highly emotional religious connotation. Santiago lies down on the bed in a manner suggestive of crucifixion in a scene of pain, fatigue, and selfsacrifice "Then he lay down on the bed...and slept face down on the newspapers with his arms out straight and the palms of his hands up." (OMS, p.105), displaying love and kindness to Manolin and even to his rival (the fish) parallels the relationship between Christ and his disciples, Manolin's crying corresponds to the supporters of Christ and their guilt after the crucifixion.

Santiago loves nature as well as wildlife. He also has a deep love and sympathy for all creatures: dolphin, birds, turtles and the great marlin he is trying to kill. The hero of Hemingway finds the place of the human within nature. Santiago killed the great Marlin but had deep love and sympathy with her and his fight not from antagonism. Once he caught one of a pair of marlin: the male fish followed the hooked female all the way, and even jumped high into the air to see where his companion was when the female was hoisted into the boat. The old man thinks that was the saddest thing he had ever seen. The old man's love for the marlin is also sincere. "Fish, I love you and respect you very much. But I will kill you dead before this day ends." He will kill the fish in "all his greatness and his glory" (OMS, 47).

One of the most important manifestations of nature loved by Santiago is the image of the sea. He loved the sea and looked at as a woman. Santiago's personality is differentiated from that of his fellow fishermen in his village; his romantic attitude to the sea emphasizes his individuality within his community. He looks at the sea as a female la mar: "The old man always thought of her as feminine and as something that gave or withheld great favours, and if she did wild or wicked things it was because she could not help them. The moon affects her as it does a woman." (OMS, 24) 
Santiago's sacrifice is namely the physical pain he has to stand. Still, the life importance of this value is explicitly emphasized: "Fish," the old man said. "Fish, you are going to have to die anyway. Do you have to kill me too?" (OMS, P.26), repeated in the next fight against sharks: "I'll fight them until I die." (OMS, P.32) and emphasized by the projection into the fish: „... When the fish had been hit it was as though he were hit." or "I killed him in self-defence," (OMS, P.29). Man's desire is so strong and so important that in the attempts to reach it he is willing to bring sacrifices. Mohammed (2011) stated that "the wounds and scars on his body make him appear as a Christ-like figure; his pains and stigmata associate him with the highest Christian ideal of sacrifice and individuality."

The fishermen mocked at him but his confidence in himself has never been touched, Santiago sacrificed his life to defend his dignity. Hemingway has resembled Santiago with Christ as a way to unveil his inner power. The injuries and scars on his body make him look as a Christ-like figure; his pains and stigmata correlate him with the Christian ideal of sacrifice and individuality (Imane, 2014).

Hemingway is always conscious of man mortality believing that man is biologically trapped and doomed to suffer and die. Man is a victim of a hostile universe and this trap hangs over humanity as a whole. But, he is not made for defeat. With a dogged determination and focus, humanity can overcome the biological trap and achieve success in life. In this novel, Hemingway wanted to say that a man can be destroyed, but not be defeated. Santiago exhausted his strength to catch the giant fish and fight with hungry sharks in his return home. He showed great courage when he faced the Sharks. In his life, Santiago faced the pressures of life between despair and the spirit of life. The story of the novel teaches to always be the spirit in the face of challenge, patience, hope, friendship and love for others (Alexis, Lanior, \& Theophilus, 2014).

Santiago loved Marlin, but he had to hunt and kill him "Fish," he said, "I love you and respect you very much. But I will kill you dead before this day ends" (OMS, 14). In spite of his deep love for Marlin but he sacrificed him for the sake of his love for his people which made Santiago kill the Marlin so that more people would be fed the flesh of this fish "How many people will he feed, he thought. But are they worthy to eat him? No, of course not. There is no one worthy of eating him from the manner of his behaviour and his great dignity"(OMS, P.37).

It seems that there is a deeper more notable reason than feeding people Marlin's meat, maybe there is an internal psychological reason like introspection and feedback from others as a means to develop self-concept in referring to social psychology. Santiago wanted to get back his people's consideration, respect, and love for the second time. With the rising age, there is a period in human life that brings the urge for the resume of the existing life. In this period, the individual has to manage his physical and social changes and has to create a new self-image by these changes.

To make it, he needs to reconsider his life and harmonize with it. This period brings, in particular, a problem of psychological contrast. The existing life is evaluated and confronted with ideas and wishes, and the most required is the feeling of the meaningfulness of life or its unique case. The existential problem is supposed to be in the expression of the desire for love, harmony, and contentment. This one of the main reasons that made Santiago kill Marlin despite his deep love and respect for him.

\section{Conclusion}

The researcher discusses and analyzed selected novels of Hemingway aiming to understand how Hemingway portrayed the image of love and to give a suitable answer to the question. The researcher found that in Hemingway's novel, A Farewell to Arms the image of love was changeable. The love affairs begin with seduction and transferred into true love. The love was passionate and prolific despite the disastrous end of this relationship through the death of Catherine. Henry and Catherine's love is another portrait of Romeo and Juliet's love. While in For Whom the Bell Tolls, Hemingway portraits another kind of love, which contains the image of physical and spiritual love. Firstly, Maria tried to seduce Robert to get rid of the feelings of shame because of the accident of rape by the Fascists 
soldiers who killed her parents and raped her, but she finally finds out that only love true could eliminate shame and bad feelings.

The Sun Also Rises is dramatically different from the previous novels, Brett was in love with Jake but she could not stay with him because of his impotence. She practiced physical love with different persons. She became bitch because her lover was impotent. Finally, the portrait of love in Hemingway's the old man and the Sea was not passionate. The author discusses love from another aspect; it is the man's passion for nature and her creatures. The old man Santiago was value nature and love marlin fish but he has to sacrifice this love for the people of his village. According to the researcher's analysis, the image of love in Hemingway's selected novels was clear, essential and fundamental for the plot of the selected texts.

\section{References}

Alexis, T. A., Lanior, A. E., \& Theophilus, K. A. (2014). Overcoming the biological trap: A study of Ernest Hemingway's A Farewell to Arms and The Old Man and The Sea. Advances in Language and Literary Studies, 5(2), 166-170.

Asch, S. E. (2011). Opinions and social pressure. Scientific American magazine, 193(5), 31-35.

Assadnassab, S. (2005). Hemingway's Depiction of Women in A Farewell to Arms. Luleå University of Technology.

Fernando, G. P. (2003). Rasa Theory applied to Hemingway's 'The Old Man and The Sea' and 'A Farewell To Arms' (unpublished doctoral dissertation).Turks and Caicos Islands: St. Clements University.

Ganjoo, P. (2014). War and love in Ernest Hemingway's A Farewell to Arms. An International Refereed E-Journal of Literary Explorations, 2(4), 556-565.

Hemingway, E. (1929). A Farewell to Arms. New York: A Scribner Classic.

Hemingway, E. (1994). For whom the bell tolls. New York: Penguin Random House.

Hemingway, E. (1995). For Whom the Bell Tolls. 1940. New York: Scribner's.

Hemingway, E. (2002). The Old Man and the Sea. In Simon \& Schuster Inc. (Vol.

53). https://doi.org/10.1017/CBO9781107415324.004

Hemingway, E. (2002). The sun also rises. New York: Simon and Schuster.

Hemingway, E. (2008). For whom the bell tolls. In Simon and Schuster, New York (Vol. 35). https://doi.org/10.1017/CBO9781107415324.004

Hemingway, E. (2016). The Sun Also Rises. In Simon \& Schuster, New York (Vol.

53). https://doi.org/10.1017/CBO9781107415324.004

Imane, B. (2014). The Concept of Heroism in Ernest Hemingway's The Old Man and the Sea (Doctoral dissertation). Ouargla: Kasdi Merbah University.

Janiesch, U. (1985). For Whom the Bell Tolls by Ernest Hemingway.

Kumar, R. (2013). Amorous love in the novels of Ernest Hemingway: A romantic study of A Farewell to Arms. An International Journal in English, 4(6).

Mugair, S. K., Khadum, B. A. J., \& Khalaf, H. M. A. (2019). A stylistic analysis of For Whom the Bell Tolls. Opcion, 35(19), 903-919.

Pathan, P. S. (n.d.). A Farewell to Arms. Nmu, Jalgaon, Department of English, Faculty Membe, 1-7

Raj, S. A. (2016). Conjugal love and war in Ernest Hemingway's A Farewell to Arms. KAAV International Journal of English Fiction \& Linguistics, 3(1), 1-9.

Rubin, D. B. (1974). Estimating causal effects of treatments in randomized and nonrandomized studies. Journal of Educational Psychology, 66(5), 688.

Yu, X. (2010). The New Woman in The Sun Also Rises. English Language Teaching, 3(3), 176-179. 